Adelstein SJ, Kassis AI: Criteria for the selection of nuclides for radioimmunotherapy. In: Radiolabeled Monoclonal Antibodies for Imaging and Therapy: Potential, Problems, and Prospects, NATO Advanced Study Institute, Castelvecchio Pascoli, Italy, July 20-August 1, 1986, in press

CRITERIA FOR THE SELECTION OF NUCLIDES FOR RADIOIMMUNOTHERAPY

S. James Adelstein and Amin I. Kassis

CONF-8607355--1

Harvard Medical School

DE98 002584

Boston, MA 02115

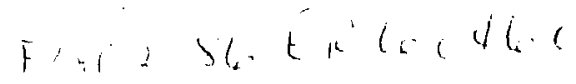

INTRODUCTION

For a number of years the scientific and medical communtties have contemplated the possibllity of using radicnuclides for therapy in cancer. The use of sealed sources, such as radium needles and capsules, is now commonplace. With the exception of a relatively select number of applications, the hopes for employlng unsealed sources are still unrealized. The problem has two compotsents: the first, and the subject of this conference, is the discevery of a proper carrier molecule with which to bring the radionuclide into the vicinity of the cancer; the second involves interactions between the radjonuclide and its blological environment, the radiation biology of the decay products. The accurate estimation of absorbed dose requires information about: the antibody - its specificity, immunoreactivity and stability; the biology of the cancer cell - the number of accessible antigenic sites and their affinity, the homogeneity of antibody presentation among the cancer cells, Internalization and modulation of the antigen antbody complex, stability of the complex, stabilicy and translocation of the label out of the complex, and the relationship of antigenicity to the cell cycle; the degree of natural immune survelllance; and the microenvironment of the tumor - its vascularity, its vascular permeability, oxygenation, microscopic organization and architecture including the mobility of the cells, their location and accessibility to intralymphatic, intraperitoneal, intracerebral and intramedullary pathways. In addition, certain propertles of the radlonuclide to be selected must be known: its mode of decay, including the nature of the particulate radiations and their energies; its physical half-1ife; and its chemistry in relation to the carrier molecule. Given all this, it is concelvable that sometime in the future one could select a radionuclide for the treatment of a specific tumor taking into account the clinical problem; for example, is one treating microscopic or bulk disease, is one attempting a cure or palliation? In these cases a specific prescription could be written much as the surgeon selects the approprlate operation, the chemotheraplst the proper reagent, or the radiotherapist the proper radiation field for treatment. 
1. The radiations from varlous radionuclides have different levels of linear energy transfer (LET) and radiobiological effectiveness (RBE). Beta particles are of low LET, and the radioblological response to them is in accordance, 1.e., the RBE is near unfty with respect to $x$-rays in terms of energy deposition, and there is a strong oxygen dependence with well oxygenated cells having a greater radiation sensitivity than less well oxygenated ones. Therefore, with an hypoxic tumor core, there is a mixed uncertain blological response to a given radiation dose. Alpha particles are of high LET. They are more biologically effective than beta particles (on an energy-deposited basis), and their cumoricidal effects are much less oxygen dependent.

2. Radiation responses are generally related to the volume of tumor. Because dose-survival curves for cells are exponentlal, for a given dose the probability of cell eradication is inversely related to the volume, 1.e., the number of cancer cells. For example, if one cell is required to maintain a tumor and the radiation dose treats to a survival fraction of $10^{-5}$, with $10^{4}$ cells the chance of one cell surviving is one out of ten or $90 \%$ theoretical chance of sterilization; with $10^{5}$ cells, the probability of one cell surviving is quite good. (A tumor containing $10^{4}$ cel.ls has a diameter of about $0.3 \mathrm{~mm}$, while a tumor containing $10^{5}$ has a diameter of about I mm.) For this reason, large tumors are unlikely to be amenable to cure except at enormous doses, and it is often advantageous to precede radionuclide therapy with a surgical debulking procedure.

3. The doses required to sterllize dividing cells (cancer) are usually less than those required to $\mathrm{klll}$ well differentlated ones (thyrotoxicosis), thousands of rads versus tens of thousands of rads. Unlike the treatment of thyrotoxicosis where functioning intermitotic cells must be killed, for the treatment of cancer the object is to keep the cells from further division.

4. The radiation from radionuclides is generally prolonged in time. This means that the calculated dose is less effective than it would have been if Instantaneously delivere.. It also suggests that repalr processes at work during the perlod of protraction may spare normal cells relative to cancer cells. As has been made clear in other papers, normal tissue tolerance, espectally bone marrow tolerance, is of ten the factor that limits our ability to deliver a tumoricidal dose.

5. Hyperthermic techniques and anoxic cell sensitizers, adapted to external beam radiotherapy so as to even out the effective dose between oxygenated and hypoxic portions of tumors, can also be utilized in radionuclide therapy.

6. The consequences for nontarget tissues must be addressed: a) Acute (short-term) effects on normal proliferating tissues including depression of the bone marrow after Intravenous injections and of the gastrointestinal tract after intraperitoneal injections. In these cases we are concerned about hundreds of rads. By fractionating the administered doses, these effects may be ameliorated to some degree. b) Midterm effects on moderately radiation-sensitive tissues that may recelve high doses (in the thousands of rads) where the effects appear to be due principally to vascular damage, for example, radiation hepatitis, nephritis, preumonitis, and chronic gastroIntestinal changes. c) Long-term effects with the appearance of second cancers. This concern need only emerge when one begins to see cures or - long-term survivors and the use of these procedures in many cancer patients. Even if they appear, they are not likely to be a deterrent to the continued use of an efficacious treatment. For example, assume a bone marrow dose of 100 rads as a consequence of radiolmmunotherapy; the probability of leukemia In a long-term survivor is about 1 in 100 . 
The properties one looks for in a radionuclide that is to be used for therapy depend to a large degree on its location in relation to the target cells. Different considerations will prevall if the radionuclide is located o.tside of $t h=$ cancer cell, on tts surface, in its cycoplasm or in 1 ts nucleus. Keep in mind that the radiation sensitive region of the cell is the cell nucleus. Based on the above, one can examine three modes of decay: beta decay, alpha decay, and electron capture with the emission of Auger and Coster-Kronig electrons. Each of these types of decay has particles of varying range and hence effective distance as well as differences in relative biological effectiveness.

\section{Beta Decay}

Current radionuclide therapy is based exclusively on beta-emitting radioisotopes. Although in theory both positively and negatively charged particles could be employed, in practice only negatrons are used. Positrons have a range of about $1 \mathrm{~mm}$ in tissue before they annihilate to form a pair of photons. The possibility of using them as particles for therapy and simultaneously locating them by annihilation photon tomography has not, to our knowledge, been explored.

Negatively charged beta particles are emitted in continuous values of energy up to a maximum and thus have a distribution of ranges. The average energy of an emitted beta particle is approximately one-third of its maximum energy, and the range in mn is approximately the maximum energy in MeV divided by 0.2 . Typically, these light charged particles travel in contorted paths during their interaction with matter. Their track structure is probably more of interest to those working in the field of radiolmmunotherapy than has previously been appreclated since the relatively uniform irradiation of tissue assumed for beta-particle emitters independent of their microscopic distribution may be substantially incorrect. Evidence from microautoradiography and from minlature dosimeters suggests that there may be considerable heterogeneity at the hundreds, if not tens, of micron range. 1,2

Some beta-emitting radionuclides are given in Table 1. The list shows the range of energles and distances that can be covered by beta emitters. of importance to dosimetry is the equilibrium dose rate constant $\left(\Delta_{1}\right)$ in gram-rad per microcurle-hour. This value, when given for the particulate radiation only, reflects the localized radiation dose to be expected from a given quantity of any radionuclide when distributed uniformly in a tissue.

Many beta-particle-emitting radionuclides release gamma photons as well. These photons may be used to locate the distribution of the radionuclide and estimate its quantity; they generally do not add significantly to the dose delivered to the target tissue but, unfortunately, may contribute unwanted radiation dose to nontarget tissues. This gamma radiation can add considerably to the whole body and espectally the bone marrow component of dose; for example, 100 millicuries of lodine-131 distributed throughout the whole body provides about 60 rads per day. For radionuclides that emlt beta particles of high energy only, the accompanylng bremsstrahlung can be used to locate the radionuclide in the body.

In order to galn some appreclation of these delivered doses, we have taken the equilibrium dose rate constants for lodine-131 and yttrium-90 and combined them with pharmacokinetic data provided by Dr. Gerald DeNardo in his paper. ${ }^{3}$ Assume that one desires to treat a 2-cm diameter nodular tumor with efther a radiolodinated or radioyttriated monoclonal antibody. Assume further that the yttrium labeled entibody confugate behaves like an Indium 


\begin{tabular}{rrccc}
\hline Isotope & Half-11fe & $\begin{array}{c}E_{B}-(\max ) \\
(\mathrm{keV})\end{array}$ & $\begin{array}{c}\text { Range }(\max ) \\
(\mathrm{mm})\end{array}$ & $\begin{array}{c}\Delta_{1}{ }^{\mathrm{b}} \\
(\mathrm{g}-\mathrm{rad} / \mu \mathrm{Cl}-\mathrm{h})\end{array}$ \\
\hline $169 \mathrm{Er}$ & $9.4 \mathrm{~d}$ & 350 & 1.0 & 0.22 \\
$121 \mathrm{Sr}$ & $27.1 \mathrm{~h}$ & 380 & 1.2 & 0.24 \\
$67 \mathrm{Cu}$ & $61.9 \mathrm{~h}$ & 580 & 2.2 & 0.33 \\
$131 \mathrm{I}$ & $8.0 \mathrm{~d}$ & 610 & 2.4 & 0.40 \\
$127 \mathrm{Te}$ & $9.4 \mathrm{~h}$ & 700 & 2.9 & 0.48 \\
$83_{\mathrm{Br}}$ & $2.4 \mathrm{~h}$ & 920 & 4.2 & 0.68 \\
$143 \mathrm{Pr}$ & $13.6 \mathrm{~d}$ & 940 & 4.2 & $0.67^{*}$ \\
$198 \mathrm{Au}$ & $2.7 \mathrm{~d}$ & 960 & 4.4 & 0.69 \\
$109 \mathrm{Pd}$ & $13.5 \mathrm{~h}$ & 1030 & 4.8 & 0.73 \\
$186 \mathrm{Re}$ & $90.6 \mathrm{~h}$ & 1070 & 5.0 & 0.95 \\
$165 \mathrm{Dy}$ & $2.3 \mathrm{~h}$ & 1290 & 6.4 & 1.48 \\
$32 \mathrm{P}$ & $14.3 \mathrm{~d}$ & 1710 & 8.7 & 1.66 \\
$188 \mathrm{Re}$ & $17.0 \mathrm{~h}$ & 2120 & 11.0 & $1.72^{*}$ \\
$142 \mathrm{Pr}$ & $19.1 \mathrm{~h}$ & 2160 & 11.3 & 1.99 \\
$90 \mathrm{Y}$ & $64.1 \mathrm{~h}$ & 2280 & 12.0 & \\
\hline
\end{tabular}

a. Calculated using $E=5.9(R+0.007)^{0.565}+0.00413 R^{1.33}-0.367$

Where $R=$ range in $\mu \mathrm{m}$

$E=\operatorname{maxtaum} B^{-}$energy in $\mathrm{keV}$

See A. Cole, Radiat Res. 38:7 (1969).

b. $\Delta_{1} \equiv$ average equilibrium dose rate constant for beta radiation. All values obtained from ICRP Publication 38; exceptions: * values from NCRP Report 58 .

labeled one. In the case of lodine-131 labeled antibody, assume that the nodule takes up $1 \%$ of the administered dose and retains it Indefinitely so that only physical decay (half-life of 8 days) need be taken into account. The remainder of the administered dose is retained uniformly in the body with an effective half-life of one day. For yttrium-90, again assume that $1 \%$ of the administered dose is taken up by the nodule and retalned; in this case, the physical half-life is 64 hours. The remainder of the administered activity is retained uniformly in the body with a biological half-1ife of 7 days, giving an effective half-1ife of 46 hours. Under these circumstances, 50 millicuries of lodine-131 will deliver 13,500 rads to the tumor nodule and approximately 42 rads to the whole body. In the case of yttrium-90, 31 millicuries will deliver 13,500 rads to the tumor and 82 rads to the whole body. Less yttrium-90 than lodine-131 is required to deliver the same dose to the tumor because of the higher energy (and consequently higher equilibrium dose rate constant) associated with its beta decay. On the other hand, the longer whole body retention for yttrium assumed in this instance makes for a larger whole body dose. As one can see, the dosimetry of these internal emitters depends not only upon the physical properties of the radionucilde but upon the pharmacokinetics and distribution of the labeled antibody as well.

\section{Alpha Particles}

Alpha partfcles are helium nuclei that travel in stralght lines with a deposition of considerable ercigy along their rracks (about $100 \mathrm{keV}$ per micron for usable nuclides). Alpha-emitting radionuclides would have some advantages for therapy. The high LET radiations have correspondingly high 
RBE and little oxygen dependence. Moreover, relatively few decays are needed to Inactivate the cell. Because the range is relatively short (5-10 cell diameters), it is possible to confine the radiation to tumor cells with high therapeutic ratio (radiatior of cancer cells with considerablo naring of normal cells). A disadvantage of alpha-particle-emltting radionuclides is that they require most cancer cells or their nearest neighbors to be labeled in order for all cells to be Irradlated. Moreover, the deposition of energy in noncancer cells also is of high RBE and Increases the likelihood of elssue damage and second cancers.

Two radionuclides have been suggested for therapy: astatine-211 and blsmuth-212. More recently, B1gler has suggested the possible use of ferralum-255.4 Astatine-211 has a half-11fe of 7.2 hours, and an average alpha particle energy of $6.8 \mathrm{MeV}$ with a particle range of approximately 65 microns. B1smuth-212 has a half-life of 1.1 hours and an alpha particle energy of $5.6 \mathrm{MeV}$ with a range of 54 microns. The half-life of fermium-255 wh1ch is 20 hours may be the most favorable. Astatine, the heaviest halogen, has a chemistry that resembles lodine in some ways, and bismuth behaves somewhat like lead.

Although bismuth-212 labeled monoclonal antibodies have been used experfmentally to destroy some immunocompetent cells, the radiation blology of astatine-211 has been worked out in somewhat more detall. In vitro dosesurvival studies of cells in suspenston have shown a monoexponentfal survival curve (Figure 1 ) with a $D_{0}$ of 29 rads; for cells in monolayer, the $D_{o}$ is 48 rads. Modeling from these survival curves indicates that approximately 1.5 nuclear traversals deliver a mean lethal dose. 5

When the radionuclide can be confined to the tumor cell corpartment, alpha-particle-emitting radlonuclides have been demonstrated to be effective in experimental cancer treatment. An astatine collold can be prepared from tellurfum particles (2-25 micron diameter) and, when given to mice implanted with ovarian ascites tumor cells, has been shown both to prolong survival and to result in cures. ${ }^{6,7}$ Indeed, when compared with other radionuclidecontalning collolds a 50\% Increase in median survival has been found with 15 microcurtes of astatine-211, 100 microcuries of phosphorus-32, 200 microcurles of yttrium-90 and 5 millicuries of dysprostum-165. No cures have

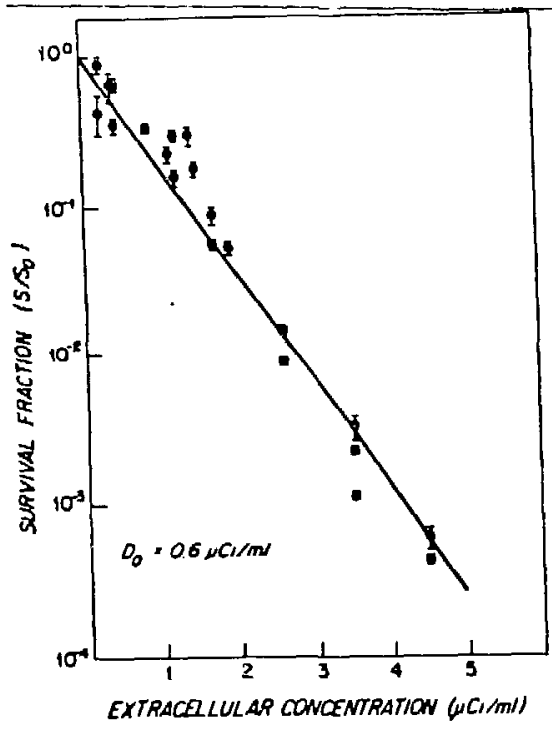

Fig. 1. Dose-survival response of 779 cells in suspension exposed to various concentrations of $211_{A t}$. Reprinted with permission from Rad1at Reg. 105:27 (1986). 
been seen with any of the beta emitters under circumstances in which cures

have been obtalned with the optimal dose of astatine-2ll (Figure 2).

Electron Capture with Auger and Other Low-Energy-Electron Emission

The response of a cell to the decay of an Auger emttcer depends on the cellular localization and concentration of the radionuclide. Two different effects can be described. The extreme radiotoxiclty assoclated with the Auger effect is observed when a shower of Auger and Coster-Kronig electrons with energies ranging from a few to several hundred electron volts is emitted by the radionuclide in the vicinity of nuclear DNA. As a result, extremely high localized doses are produced in microscopic volumes 5 to 10 nanometers in diameter. It has been shown that when the radionuclide is Incorporated Into one of the pyrimidine bases such high specific ionization results in multiple strand breaks close to the site of decay in DNA and oligonucleotides.8 In addition, the decay of lodine-125 when part of a pyrimidine base results in the disintegration of the pyrimidine ring. 9 Such molecular lesions would be expected to have profound blological effects, and these have been show in a number of instances. For example, dose-survival curves for cells labeled with lodine-125 lododeoxyuridine are high LET-like In their appearance with no shoulder on the survival curve and a very steep slope.10 Similar observations are made when chromosomal aberration frequencles are measured, with lodine-125 belng moch more effective than lodine-131. These results are observed with other Auger-emitting radionuclides, such as lodine-12311 and bromium-77,12 when Incorporated into the nuclear materials as halogenated pyrimidine nucleosides. Thus, when these radionuclides are deposited in the cell nucleus, there is a high LET-like radioblological response with relatively few decays required to inactivate a cell.

On the other hand, when an Auger-electron emitter is present in large quantities in the cytoplasm or on the surface of target cells, the longerrange but still relatively low-energy electrons can still reach the nucleus and produce cell death, albelt with a lesser efficiency. This is demonstrated by the dose-survival curve of cultured cells labeled with lododi-

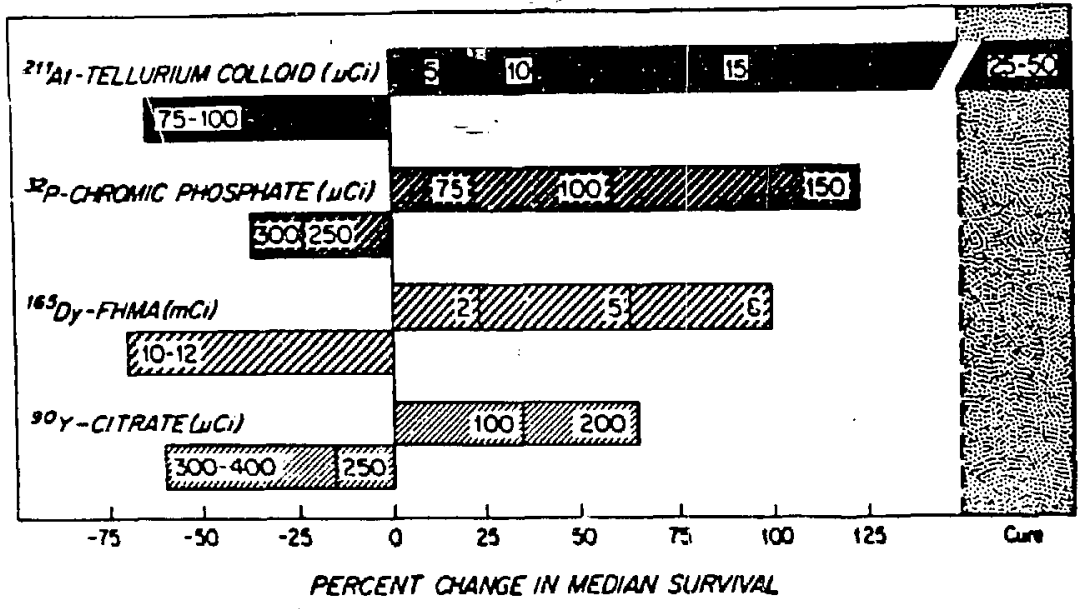

Fig. 2. Radiocollold therapy on experimental malignant ascites in mice, expressed as the percentage of change in median survival. Reprinted with permission from Int J Radiat Oncol B1ol Phys.,10, W. J. Bloomer, W. H. McLaughlin, R. M. Lambrecht, R. W. Atcher, S。 Mirzadeh, J. L. Madara, R. A. Milius, M. R。 Zalutsky, S. J. Adelstein, and A. P. Wolf, $211_{\text {At }}$ radiocollold therapy: Further observations and comparison with radiocollotds of $32 \mathrm{P}, 165 \mathrm{Dy}$, and $90 \mathrm{Y}$, copyright 1984 , Pergamon Press, Ltd. 
hydrorhodamine, a dye that is concentrated in the cytoplasm.13 A comparison of the dose-survival curve of cells incubated with lodine-125 labeled 1ododihydrorhodamine with that of cells Incubated with lodine-125 labeled lododeo iyuridine (Incorporated into the nuclear material) is shown in Figure 3. Inlike the curve for lododeoxyuridine, the survival curve following the cytoplasmic incorporation of lododihydrorhodamine has a distinct shoulder and a shallower slope resembling that found with lodine-131 labeled lododeoxyuridine.

When other radionucliues that decay by electron capture are concentrated by cells, a good portion of the radiation dose recelved by the cell is from its own intracellular radioactivity. This is in contrast to the usual beta-emitting radionuclide where the principal sources of radiation exposure are radiations from other cells and from the extracellular flutd. For example, the monovalent cations potassium-43 and rubidium-86, which decay by beta minus emissions, and thallium-201, which is an Auger-electron emftter, are concentrated by mammalian cells. It has been shown that thallium-201 1s much more toxic to dispersed cells than potassium-43 and rubldium-86 on a per plcocurle bas1s. The maln source of radiation for the thallium-contalning cells is their own intracellular radioactivity. The exclusion of thallium by the use of ouabain or low remperatures reduces the radiation toxictity, a phenomenon that is not observed when the other cations are restricted from entering the cells. 14

It is possible that such concentration effects could be achieved by the use of monoclcaal antibodies, espectally with those that become icternalized within cells. Table 2 shows the results of an experiment 15 with three monoclonal antibodies to RINm5F cells: A2B5, AlD2 and 3G5. The cells have been lncubated $1 \mathrm{n}$ vitro with each monoclonal antibody. All three antibodies react Inttially with the cell membrane, as shown by the fluorescence which decays with a half-life of approximately one hour. Following 24 hours in antibody-free medium, the radioactivity assoclated with A2B5 is principally retalned, while with AlD2 about $50 \%$ of the radioactivity remalns and with $3 G 5$ only about $10 \%$. Since the menbrane fluorescence has virtually disappeared by the end of three hours, it seems reasonable to conclude that the

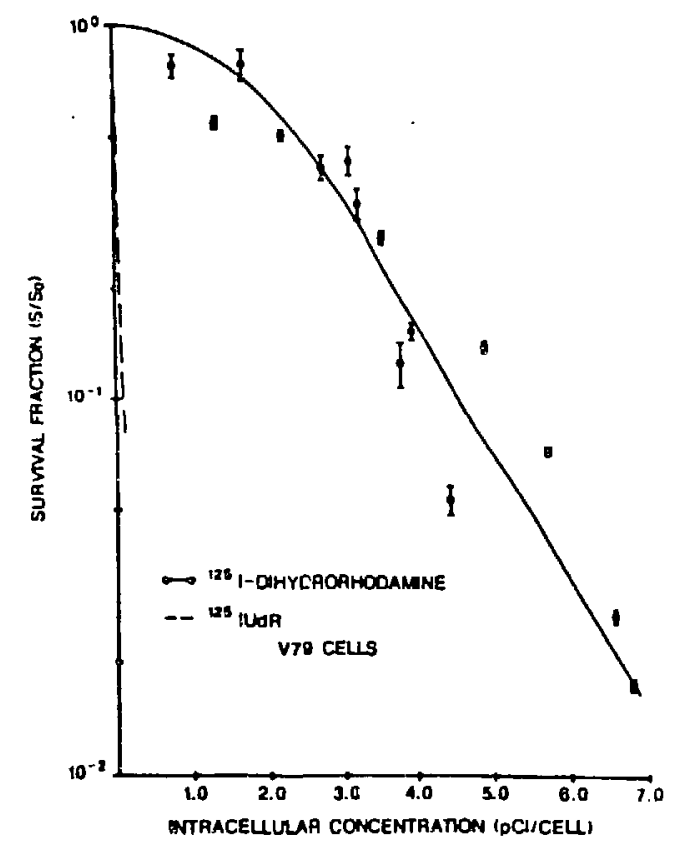

F1g. 3. Comparison of the survival of V79 cells following nuclear (125IUdR) ne netantagmin (125T-dthutrorhodamine) 1ncornoration of $125 \mathrm{~T}$. 


$\begin{array}{lcccc} & \text { Cell Membrane } & \text { Cell Associated CPM } \pm \text { SD (\% retained) } \\ \text { Time (hr) } & \text { Fluorescence } & \text { A2B5 } & \text { A1D2 } & 3 G 5\end{array}$

$\begin{array}{lccll}0.0 & 7276 \pm 1127 & 866 \pm 31 & 2109 \pm 110 \\ 1.0 & + & 466 \pm 101(53.8) & 971 \pm 65(46.0) \\ 3.0 & \pm & 6949 \pm 1068(96) & 490 \pm 23(56.6) & 590 \pm 80(28.0) \\ 24.0 & 5922 \pm 1302(81) & 595 \pm 15(68.7) & 200 \pm 50(10)\end{array}$

retalned radioactivity is within the cell. Under these circumstances, labeling with radtoruclides that emit electrons of short range (several microns) could have a high therapeutic ratic, the decays belng espectally toxic to cells in which the radionuclide is internalized and much less toxic to cells from which it is totally excluded.

\section{SUMMARY AND CONCLUSIONS}

Many factors need to be taken into account and many problems resolved if radiolmmunotharapy is to become a commonplace reality. Among these are the radioblological aspects. For beta-emitting radionuclides, the two physical features of Importance are half-11fe and energy, with the latter determining the range. These features will have to be matched to the pharmacokinetics of the carrier and the distribution of the radionuclide, both macroscoplcally and microscoplcally. Alpha-particle emitters could be considered for cells that are readily accessible to the labeled antibody and for populations which unfformly and constantly display the targeted antigen or 1diotype, e.g., trafflcking cells such as $T$ or $B$ lymphocytes. For cells that concentrate the radioactive label (by internalization, transchelation, etc.), the use of low-energy electrons should be examined. If the radionuclide is translocated to the nucleus, the Auger effect can be particularly lethal because of the high LET-11ke biological response.

\section{ACKNOWLEDGEMENT}

The authors wish to thank Evelyn E. Watson, Oak Ridge Associated Universities, for providing us with the average equilibrium dose rate constants Including those from ICRP Publication 38 and NCRP Report 58.

\section{REFERENCES}

1. S. J. DeNardo, The design of a radiolabeled monoclonal antibody for radiolmmunotherapy, in: these proceedings.

2. W. P. Neacy, B. W. Wessels, E. Bradley, S. Kovandi, T. Justice, S. Danskin, and H. Sands, Comparison of radioimmunotherapy (RIT) and 4 MV external beam radiotherapy of human tumor xenografts in athymic mice, J Nucl Med. 27:902 (1986).

3. G. L. DeNardo, Quantitative pharmacokinetics of radiolabeled monoclonal 
antibodies in patients, in: these proceedings.

4. R. E. Bigler, Adjuvant radiolmmunotherapy for micrometastases: A sirategy for cancer cure, $1 \mathrm{n}$ : these proceedings.

5. A. I. Kassis, C. R. Harris, S. J. Adelstein, T. J. Ruth, R. Lambrecht, and A. P. Wolf, The in vitro radiobiology of astatine-211 decay, Radiat Res. 105:27 (1986).

6. W. D. Bloomer, W. H. McLaughlin, R. D. Neirinckx, S. J. Adelstein, P. R. Gordon, T. J. Ruth, and A. P. Wolf, Astatine-211-tellurlum radiocollold cures experimental malignant ascites, Science 212:340 (1981).

7. W. D. Bloomer, W. H. McLaughlin, R. M. Lambrecht, R. W. Atcher, S. Mirzadeh, J. L. Madara, R. A. Milius, M. R. Zalutsky, S. J. Adelstein, and A. P. Wolf, $21 l_{\text {At }}$ radiocolloid therapy: Further observations and comparison with radiocollolds of $32 \mathrm{P}, 165 \mathrm{Dy}$, and $90 Y$, Int J Radiat 0ncol Biol Phys. 10:341 (1984).

8. R. F. Martin and W. A. Haseltine, Range of radiochemical damage to DNA with decay of lodine-125, Sclence 213:896 (1981).

9. U. Linz and G. Stocklin, Chemical and blological consequences of the radioactive decay of Iodine-125 in plasmid DNA, Radiat Res. 101:262 (1985).

10. E. W. Bradley, P. C. Chan, and S. J. Adelstein, The radiotoxicity of lodine-125 in mammalian cells I. Effects on the survival curve of radiolodine tncorporated into DNA, Radiat Res. 64:555 (1975).

11. A. I. Kassis, K. S. R. Sastry, and S. J. Adelstein, Intracellular localisation of Auger electron emtters: Biophysical dosimetry, Radiat Prot Dosim. 13:233 (1985).

12. A. I. Kassis, S. J. Adelstein, C. Haydock, K. S. R. Sastry, K. D. McElvany, and M. J. Welch, Lethality of Auger electrons from the decay of bromine-77 in the DNA of mammalian cells, Radiat Res. 90:362 (1982).

13. S. J. Adelstein, A. I. Kassis, F. Fayad, B. Kinsey, W. W. Layne, and K. S. R. Sastry, Radiotoxicity of 125 I following cytoplasmic decay, 1n: "Abstracts of Papers for the Thirty-Fourth Annual Meeting of the Radiation Research Soclety, Las Vegas, Nevada, Apri1 12-17, 1986 ".

14. A. I. Kassis, S. J. Adelsteln, C. Haydock, and K.S.R. Sastry, Thallium201: An experimental and a theoretical radiobiological approach to dosimetry, J Nuc1 Med. 24:1164 (1983).

15. A. I. Kassis, C. N. Venkateshan, W. W. Layne, G. Elsenbarth, A. Kaldany, B. M. Kinsey, and S.J. Adelsteln, Paper 120, Iodinated monoclonal antibody internalization by tumor cells, $1 \mathrm{n}$ : "Sixth International Symposium on Radiopharmaceutical Chemistry, Boston, June 29-July 3 , 1986, Abstracts".

\section{DISCLAIMER}

Glus report was prepared as all account of work spunsored by an agency of the linited States (itvernment Nettuer the United States Government nor any agency thereof. nor any of their employess, makes any warranty, express ur implied, ur assumes any legal liahility or responsibility for the accuracy. completeness. or usefulness of any information, apparatus, product, ur prixess disclesed, or represents that th use would not infonge privately owned rights Reference herein io any nectíc cummercial product. process, or service by trade name, trademark. manufacturer, or otherwise does not necessarily constitute or imply its endorsement, recom. mendatson, or favoring by the United States Government or any agency thereof. The views and opinions of authors expressed heren do not necessarily state or reflect those of the United States Government or any agency thereof. 